\title{
The conception and countermeasures of "green hydrogen" industrial chain in Chengdu area
}

\author{
Li-min zhang ${ }^{1}$,Rong-hu zhang ${ }^{2, *}$ \\ ${ }^{1}$ Sichuan-Tibet Planning and Development Centre of China Datang Corporation,chengdu,china \\ ${ }^{2}$ Datang Sichuan Power Generation Co.,Ltd.Renewable Power Branch,chengdu,china
}

\begin{abstract}
With the application of hydrogen energy in the world, photovoltaic hydrogen producton industry has been ignited rapidly. Many Chinese governments and companies are producing hydrogen, often called "green hydrogen", from renewable sources. Japan, Germany. The Netherlands, Australia, Canada and other countries have carried out research or investment in large-scale photovoltaic hydrogen production projects. This article takes the hydrogen energy planning of Chengdu, Sichuan Province as the lead, and combines the actual conditions of the Ganzi region to discuss the feasibility of using photovoltaic power generation to produce hydrogen to support the development of the hydrogen energy industry in Chengdu under the conditions of abundant photovoltaic resources and no transmission.
\end{abstract}

\section{Introduction}

Sichuan province has gathered more than 50 enterprises and institutes in the hydrogen energy industry chain, covering major links such as hydrogen preparation, storage and transportation, charging, filling, fuel cell, vehicle manufacturing and hydrogen station construction. A complete industry chain has been preliminarily established with huge development potential. But the current production of hydrogen are basically "blue hydrogen", in the production process will be a certain amount of carbon dioxide emissions, the whole industry chain has not yet formed green development, through on-the-spot investigation, the author envisions in northwest sichuan province ganzizhou ganzi county building photovoltaic power station and its surrounding areas, hydrogen production plant located in xindu bridge, it is the best solution, using the ganzi county to $220 \mathrm{kv}$ line, xindu bridge will have a power to power plant, hydrogen production plant, xindu bridge using trucks to transport hydrogen chengdu regional sales, formed a set of electricity, hydrogen production, hydrogen storage, hydrogen, hydrogenation in the integration of green, the hydrogen production chain, The economic model of direct hydrogen production from solar energy has been feasible to some extent.

\section{DEVELOPMENT PROSPECT
HYDROGEN ENERGY DEMAND IN \\ $\begin{array}{lll}2 \text { DEVELOPMENT PROSPECT OF } & \text { OF } \\ \text { HYDROGEN ENERGY DEMAND IN }\end{array}$ SICHUAN}

2.1 Chengdu's automobile industry has a good foundation. The conversion of stock and the addition of new vehicles will create a huge market space for new energy vehicles in Chengdu.

By the end of 2019, the chengdu motor vehicle ownership of more than 5.8 million vehicles, annual average increment in recent six years more than 480000 vehicles, second only to the ownership of Beijing, the second, in the chengdu car ownership in the second, the traditional car has great pressure of environmental pollution, motor vehicle exhaust emission of PM10 and PM2.5 comprehensive contribution rate has reached $25.5 \%$ and $30.5 \%$ respectively, become the important sources of atmospheric environment quality.

By the end of 2018, Chengdu Public Transport Group had 13,939 registered buses, 1,501 new pure electric buses, 147 sets of charging piles and 786 lines in operation, with a total mileage of 470 million kilometers and a total passenger volume of 1.5 billion.

By March 26, 2019, A total of 73,500 new energy vehicles had been promoted in Chengdu. (Among them, 36,500 vehicles had been promoted in public transportation sectors such as rental, online booking and leasing.) 20,600 vehicles were promoted in the field of logistics and distribution; In private consumption, 14,100 vehicles were promoted; Party and government organs and public institutions to promote 819).

\subsection{Chengdu hydrogen fuel vehicles started early and have initially presented a development roadmap.}

\footnotetext{
* Corresponding author: 675908096@qq.com
} 
The P09 bus demonstration line in Chengdu's Pidu District is officially launched in April 2018. As the first in Sichuan and the second in China, after more than a year of operation, operation indexes such as bicycle operating mileage and average hydrogen consumption are among the best operational indexes in China. The vehicle is traveling to and from the passenger center station of Pidu District to Tangchang bus station, with 34 bus stations in the whole process. The cycle runs 4 times a day, and the round trip is about 50 kilometers, which takes about 2 hours. Each car carries about 500 passengers every day, and the average hydrogen consumption of 100 kilometers is less than $3.4 \mathrm{~kg}$.

In 2019, a project of 90 fuel-cell bus demonstration line in Pidu District is expected to be launched before the Spring Festival of 2020. Chengdu is the second city with more than 100 hydrogen-fueled buses online in China, and the hydrogen energy and fuel cell industry is the development highlight of new industries in Chengdu and even Sichuan province.

Chengdu already has two stationary hydrogen refueling stations, which will be completed and put into operation in 2019 and 2020 respectively.

\section{ABOUT PHOTOVOLTAIC AND HYDROGEN PRODUCTION}

Ganzi Prefecture in Sichuan province is rich in solar energy resources, which can use about 56 million $\mathrm{kW}$. The northern region of Ganzi is mainly covered by Shiqu, Dege, Ganzi, Luhuo, Seda, Xinlong and Baiyu counties, with the average annual solar radiation value of most areas exceeding $6500 \mathrm{MJ} / \mathrm{m}^{2}$, with more than 2,400 hours of sunshine per year, it has the best solar energy resource conditions in the whole state, belongs to the national solar Energy A resource, and has the conditions for building solar photovoltaic power stations. Less than
$1 \%$ of the region's solar energy resources have been developed because of the region's problems.

Photovoltaic hydrogen production technology is to convert solar energy into electric energy. Electric energy is converted into hydrogen through electrolysis of water hydrogen production equipment, and hydrogen is transferred to the hydrogen application terminal to complete the conversion from solar energy to hydrogen energy.

Photovoltaic hydrogen production technology, as a new way of energy storage, mainly involves two key technologies: electric hydrogen conversion and hydrogen storage and transportation. The entire technical process includes photovoltaic power generation and transmission, electrolytic water hydrogen production system, hydrogen storage system and hydrogen transport system. According to the control requirements after taking power, through the $\mathrm{AC} / \mathrm{DC}$ conversion, hydrogen production by electrolysis of water, the system of hydrogen storage in medium voltage hydrogen-storage tanks first, and then, through $20 \mathrm{Mpa}$ hydrogen compressor filling to the bundle of hydrogen cars, according to needs to send with hydrogen, or can be medium voltage is not higher than $10 \%$ volume ratio of hydrogen concentration in mixed into natural gas pipeline in transmission.

\section{ECONOMIC EVALUATION}

\subsection{Cost analysis of photovoltaic power station:}

At present, the main costs of photovoltaic power stations include photovoltaic modules, inverters, photovoltaic mounts, photovoltaic confluents, PHOTOVOLTAIC DC and $\mathrm{AC}$ cables, fixtures and cement foundation, project design, installation costs, system debugging, monitoring system, and other unforeseen costs. The basic cost is calculated as follows (Table 1):

Table 1: Cost table of photovoltaic power station (unit: yuan/watt)

\begin{tabular}{|c|c|c|c|c|}
\hline $\begin{array}{l}\text { The serial } \\
\text { number }\end{array}$ & The name of the & model & The unit price & category \\
\hline 1 & component & Single crystal/polycrystal & $1.4-2.10$ & \multirow{7}{*}{$\begin{array}{l}\text { Equipment } \\
\text { procurement }\end{array}$} \\
\hline 2 & stents & $\begin{array}{l}\text { Aluminum alloy/hot dip } \\
\text { galvanizing/stainless steel }\end{array}$ & $0.38-0.8$ & \\
\hline 3 & inverter & $\begin{array}{c}\text { Group series/centralized/micro } \\
\text { inverse }\end{array}$ & $0.18-0.22$ & \\
\hline 4 & Junction box & $\mathrm{AC} / \mathrm{DC}$ & $0.05-0.12$ & \\
\hline 5 & cable & $2.5 \mathrm{~mm}, 4.0 \mathrm{~mm}, 6.0 \mathrm{~mm}$, etc. & 0.250 .35 & \\
\hline 6 & $\begin{array}{l}\text { Fixture/cement } \\
\text { foundation }\end{array}$ & & $0.02-0.15$ & \\
\hline 7 & $\begin{array}{l}\text { The monitoring } \\
\text { costs }\end{array}$ & $\begin{array}{l}\text { Monitoring platform, data } \\
\text { collector, irradiator, video } \\
\text { monitoring, etc. }\end{array}$ & $0.05-0.3$ & \\
\hline 8 & The design fees & $\begin{array}{l}\text { Photovoltaic power station } \\
\text { involves and grid connection } \\
\text { design }\end{array}$ & $0.1-0.2$ & design \\
\hline 9 & System debugging & & $0.05-0.12$ & \multirow{2}{*}{$\begin{array}{c}\text { Installation and } \\
\text { debugging }\end{array}$} \\
\hline 10 & Construction costs & Installation costs & $0.25-0.6$ & \\
\hline
\end{tabular}




\begin{tabular}{|l|l|l|l|l|}
\hline 11 & Other fees & $\begin{array}{c}\text { Project electricity, water, } \\
\text { unforeseeable cost, etc. }\end{array}$ & $0.03-0.1$ & \\
\hline \multicolumn{2}{|c|}{ A combined } & $2.76-5.06$ & \\
\hline
\end{tabular}

According to the above cost calculation, the construction of a photovoltaic power station with a capacity of $50,000 \mathrm{kw}$ will cost about 200 million yuan. We can also calculate the electricity price of 0.255 yuan Kwh when the full investment internal rate of return of photovoltaic power station reaches $8 \%$. However, we should also note that the construction and transportation costs of ganzi are higher than those of the mainland due to its high altitude.

\subsection{Cost analysis of hydrogen production}

Common hydrogen production technologies include hydrogen (ash) hydrogen production from coal, natural gas and oil hydrogen production, industrial by-product hydrogen (blue hydrogen), such as renewable energy sources (green) hydrogen electrolysis of water hydrogen production technology maturity is higher also, the production cost is relatively low, there are mainly alkaline water electrolysis cell (AE), proton exchange membrane (PEM) water electrolytic cell and Solid oxide water electrolyzer (SOE), and there are some case has entered the practical stage, in addition, consider the factor of carbon reduction, electrolysis of water legal system than the methods of hydrogen more hydrogen production from fossil fuels has certain social efficiency. Electricity price is the decisive factor in electrolysis of water to produce hydrogen.

If the cost of electrolysis water to produce hydrogen is calculated and split according to the normal commercial and industrial sales electricity price, it should specifically include asset depreciation, operating expenses (general maintenance, battery pack replacement), electricity charges (electricity, network), etc., among which the cost of electricity charges will reach $70-80 \%$, accounting for a relatively high proportion. See figure 1 for details:

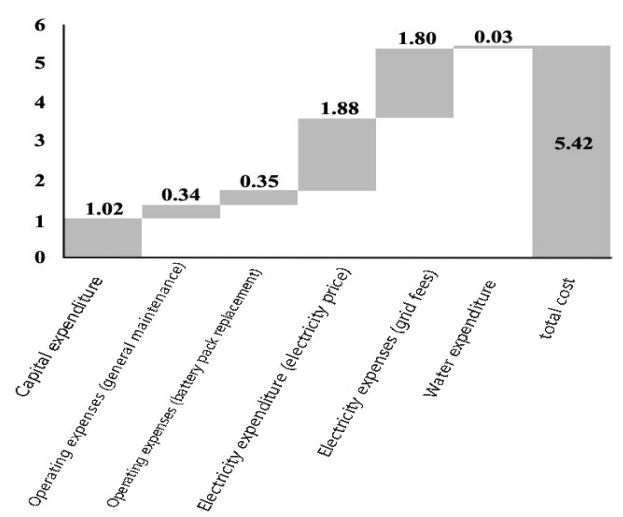

Figure 1: Waterfall diagram of cost distribution of hydrogen production from electrolytic water

Therefore, we can draw the conclusion that the most important cost of electrolysis water to produce hydrogen lies in the electricity charge. The cost of electricity determines the cost of hydrogen, and the electrolysis water to produce hydrogen needs to reduce the electricity charge cost as much as possible. Other factors, such as depreciation and operating expenses, need to be reduced through technological progress and improvement of management level. The overall proportion is relatively small and it is a long-term process.

In general, every $1 \mathrm{Nm}^{3}$ of Hydrogen consumes about $3.5-5 \mathrm{kwh}$ of electricity, that is to say, the production of $1 \mathrm{~kg}$ of hydrogen consumes 40-62 kwh of electricity. If the current market price is used as the cost of hydrogen production, the route of electrolytic water technology is not competitive. Under certain income conditions, the lower the cost of electricity and hydrogen, the more competitive the project will be.

However, if electricity with lower cost can be used for hydrogen production, that is, when the comprehensive cost of hydrogen production from electrolytic water is reduced to about 1 yuan $/ \mathrm{Nm}^{3}$ (The electricity cost of a kilogram of hydrogen is about 12 yuan), so it is economically competitive. Low-cost electricity is usually difficult to obtain, but it is expected to be realized in the process of power consumption by abandoning wind and light, which is also the core of the process of electrolytic water hydrogen production.

\subsection{Hydrogen storage and transportation cost analysis:}

At present, hydrogen is mainly transported by gas and hydrogen trailer, liquid hydrogen tank truck and hydrogen pipe. The external intake of hydrogen in domestic hydrogenation stations is transported by gashydrogen trailer, which is more suitable for the users with shorter transportation distance, lower conveying capacity and daily hydrogen consumption of ton class. The transport cost structure of liquid hydrogen tank truck is similar to that of bundle truck, but it increases the cost of hydrogen liquefaction and the boiling loss of liquid hydrogen during transport. Pipeline transportation is used in large scale and long distance hydrogen transportation, which can effectively reduce the transportation cost. The pipeline transportation mode is dominated by high-pressure gaseous or liquid hydrogen transportation.

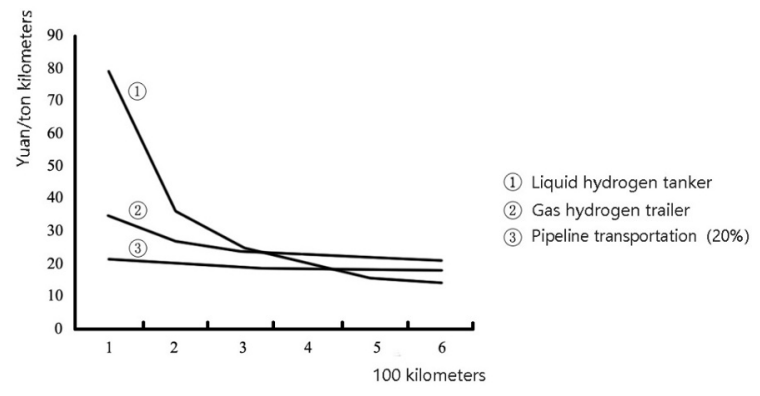

Figure 2: Cost comparison of three modes of transportation

By comparing three kinds of modes of transportation cost estimates (see figure 2), the author thinks that the 
transportation cost of pipeline has obvious superiority, but the early stage of the pipeline transport investment construction cost is higher, the hydrogen and fuel cell car industry have greater risks before maturity, the transport cost is affected by the capacity utilization rate, capacity utilization ratio, the higher the economy; Gas and hydrogen trailers have cost advantages in transportation within 300 kilometers, while liquid hydrogen takes the lead in medium and long distance transportation. Moreover, the cost advantage of liquid hydrogen after 400 kilometers is greater than that of pipeline transportation.

According to the actual investigation, chengdu is the main hydrogen distribution center in Sichuan. The author believes that the $300 \mathrm{~km}$ highway from Xindu Bridge to Chengdu is reasonably stored and transported by gashydrogen trailer $(20 \mathrm{MPa})$. The transport cost of gashydrogen trailer mainly includes: fixed cost (depreciation cost, staff salary, etc.) and variable cost (including hydrogen compression consumption electricity fee, fuel cost, etc.).

Assume that the current domestic price of container bundle trailer is about $1.2 \mathrm{million} / \mathrm{set}$ and the service life is 8 years. Each trailer is equipped with a driver and multiple operators, personnel costs a total of 500,000 yuan. The trailer is fully loaded with hydrogen up to $300 \mathrm{~kg}$ at $20 \mathrm{Mpa}$ pressure and the consumption of diesel oil is about $27 \mathrm{~L} / 100 \mathrm{~km}$.. The average running speed of the trailer is assumed to be $50 \mathrm{~km} / \mathrm{h}$, the hydrogen loading and unloading time at both ends is about 8 hours, and the annual effective working time is 4500 hours. The hydrogen compression process consumes $1 \mathrm{kwh} / \mathrm{kg}$ of electricity. It is estimated that the transportation cost per kilogram of hydrogen from the factory site (Xindu
Bridge) to Chengdu (about $300 \mathrm{~km}$ ) is about 7.5 yuan / $100 \mathrm{~km}$.

\subsection{Cost analysis of the whole process of "green hydrogen"}

To sum up, we take the production of $1 \mathrm{~kg}$ hydrogen as an example to calculate the cost and benefits of the whole process (see Table 2 for details) :

It can be seen that it is very difficult to make profits from hydrogen production by photovoltaic at present. If combined with local policies to encourage the development of hydrogen industry, it can achieve capital preservation or small profits, which will positively promote the development of hydrogen industry to some extent.

Hydrogen energy application, is a huge systematic project, only the "green" hydrogen to achieve "zero emissions", in the true sense and high energy conversion efficiency, it is considered to be one of future directions of the sustainable development of the industry, as one of the main technical path of new energy cars, hydrogen fuel cell vehicles are included in the "outline of national innovation driven development strategy, the auto industry long-term development planning, and other important strategic programs. It should also be noted that the application market of hydrogen fuel cell has not been popularized, and the supporting infrastructure is not perfect. Only with the popularization of hydrogen filling stations and hydrogen fuel cell vehicles and the sales price of actual terminals lower than that of fossil fuels, hydrogen energy can be accepted by the future market.

Table 2: Cost measurement table of the whole process

\begin{tabular}{|c|c|c|c|c|}
\hline process & project & unit & The numerical & $\begin{array}{l}\text { Measuring the } \\
\text { hypothesis }\end{array}$ \\
\hline \multirow{2}{*}{$\begin{array}{l}\text { Photovoltaic power } \\
\text { station and power } \\
\text { transmission }\end{array}$} & $\begin{array}{l}\text { Cost per kilowatt-hour } \\
\text { of photovoltaic power }\end{array}$ & 0.255 yuan & 0.255 yuan & $\begin{array}{l}\text { The electricity price is } \\
0.3 \text { yuan /Kwh }\end{array}$ \\
\hline & A net charge & 0.1 yuan & 0.1 yuan & $\begin{array}{l}\text { The net crossing fee of } \\
220 \mathrm{Kv} \text { line from Ganzi } \\
\text { County to Xindu } \\
\text { Bridge is about } 0.1 \\
\text { yuan } / \mathrm{Kwh} \text {. }\end{array}$ \\
\hline \multirow[t]{2}{*}{$\begin{array}{l}\text { Production of } \\
\text { hydrogen }\end{array}$} & $\begin{array}{l}\text { The cost of producing } \\
1 \text { kilogram of } \\
\text { hydrogen }\end{array}$ & $56 \mathrm{KWh}$ & 19.88 yuan & $\begin{array}{l}\text { Take the upper limit of } \\
\text { electricity consumption }\end{array}$ \\
\hline & Other costs & & 6 yuan & $\begin{array}{l}\text { Depreciation, material, } \\
\text { labor and other costs }\end{array}$ \\
\hline \multirow[t]{3}{*}{$\begin{array}{l}\text { Hydrogen storage and } \\
\text { transportation }\end{array}$} & $\begin{array}{l}\text { Hydrogen storage and } \\
\text { transportation costs }\end{array}$ & Yuan/kg & 22.5 yuan & $\begin{array}{l}\text { It is about } 300 \\
\text { kilometers from Xindu } \\
\text { Bridge to Chengdu }\end{array}$ \\
\hline & Other loss & & 0.45 & $\begin{array}{l}\text { The loss in storage and } \\
\text { transportation is } 2 \%\end{array}$ \\
\hline & \multicolumn{4}{|c|}{ The cost per kilogram of hydrogen is 48.83 yuan } \\
\hline \multirow[t]{2}{*}{ sell } & Sale of hydrogen & $\mathrm{kg}$ & 45 to 50 yuan & $\begin{array}{l}\text { Intake price of } \\
\text { hydrogenation station }\end{array}$ \\
\hline & \multicolumn{4}{|c|}{$\begin{array}{l}\text { The market price of hydrogen in Chengdu is about } 67 \text { yuan } / \mathrm{KG} \text {, and the bus company } \\
\text { is about } 50 \text { yuan } / \mathrm{KG}\end{array}$} \\
\hline
\end{tabular}




\section{Suggestions and prospects}

\subsection{Make effective use of cheap local electricity as the energy source of electrolysis water to produce hydrogen.}

At present, the hydropower resources in ganzi area of sichuan province is rich, but subject to regional restriction, abandoned water is serious, abandoned water power generation cost can be reduced to 0.15 yuan/degree, complete part of the refuse power could be used to develop hydrogen preparation, will greatly reduce the cost, at the same time, the bigger hydrogen preparation and its cost is lower, thus promoting renewable energy hydrogen production and form scale effect, will be more rapid decline in driving the cost of hydrogen production.

\subsection{To reduce the cost of hydrogen production and storage and transportation.}

For the hydrogen this emerging industry, not only need through short-term research and development to carry out the demonstration project, also need to research and develop the foundation work for a long time, such as looking for the ideal material for the production of electrolytic cell, through the choice of materials to further reduce the cost, improve efficiency, prolong maintenance cycle and so on, through a lot of technology to explore and research and development, from electric energy conversion efficiency of hydrogen production to a higher level $(60 \% \sim 80 \%)$. Meanwhile, with the further improvement of hydrogen storage and transportation technology, the storage and transportation cost will be further reduced.

\subsection{The combination of animal husbandry and light increases social benefits.}

At present, making full use of the complementary of photovoltaic industry and animal husbandry in Ganzi region to form a new grazing land combined with light grazing. We will actively promote the "photovoltaic + animal husbandry" model, which can not only make intensive use of land, but also help farmers and herdsmen in Ganzi to broaden their sources of income and help local poverty alleviation, with obvious social benefits.

China's wind power, photovoltaic and other new energy hydrogen production projects are more of a demonstration of the initial stage, only gradually solve the problems in the development, the courage to innovate, to promote the photovoltaic hydrogen production industry into the mature period.

\section{References}

1. Hua-tang Yuan. Hydrogen energy: the most important energy in the $21 \mathrm{st}$ century [J]. ( International academic trends. 1998.12)
2. Chun-mei Jing. QI-xiang He, The development of China's hydrogen energy from the perspective of Japan and South Korea's hydrogen energy industry [J]. (energy. 2019.12)

3. Fen Chen. Thoughts on sustainable energy development in China [J]. (China's economic information. 2013.09)

4. Wen Bo. Spring of renewable energy in China [J]. (Green China. 2006.13) 